\title{
Agritourism enterprises on your farm or ranch: Understanding regulations
}

HOLLY GEORGE, UC Cooperative Extension Livestock and Natural Resource Advisor, Plumas and Sierra Counties; and ELLIE RILLA, UC Cooperative Extension Community Development Advisor, Marin County

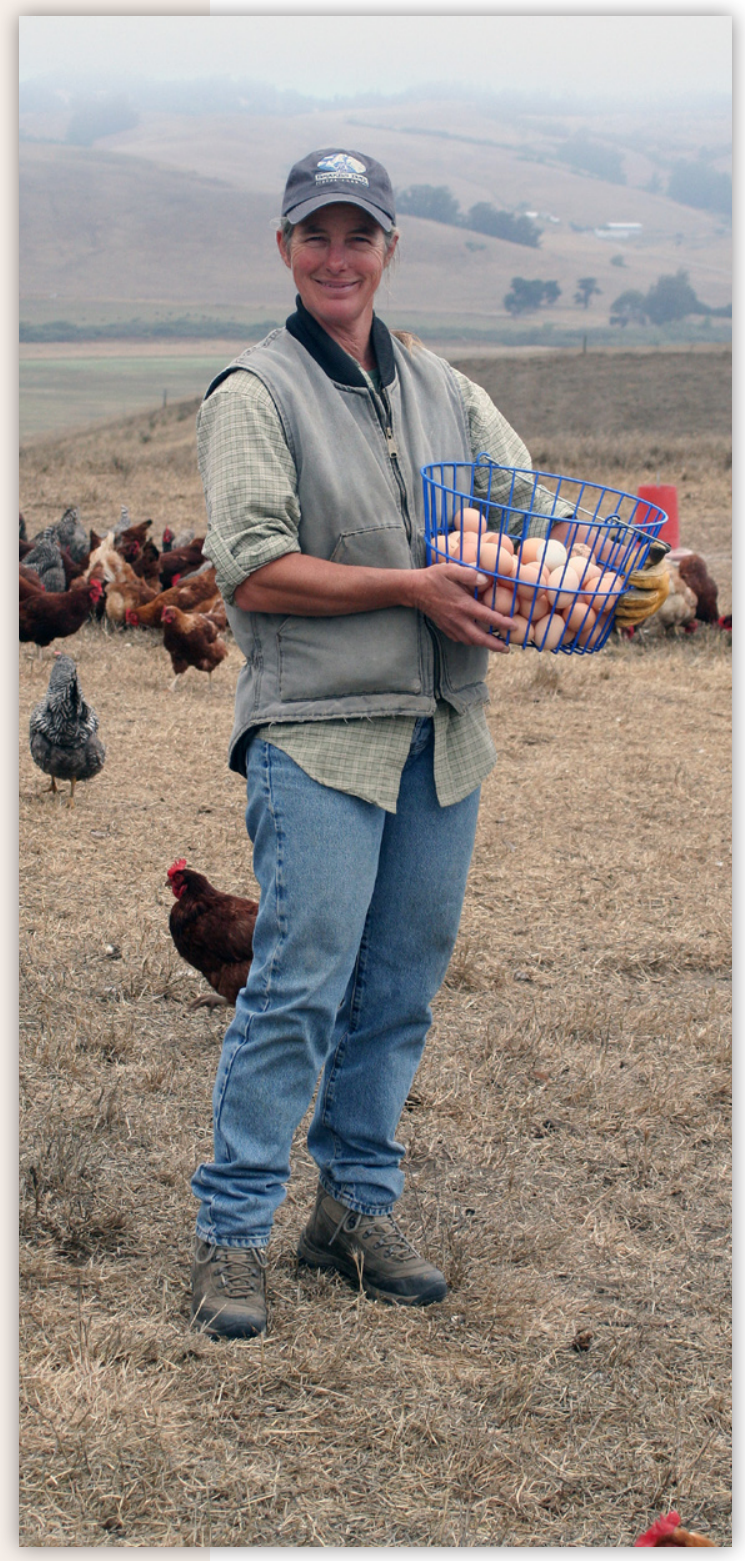

Agritourism in California has the potential to profitably direct market farm products and services, to serve as an alternative use of farm and ranch land, or to supplement your farm income. But numerous regulations-many complex-face landowners interested in establishing an agritourism enterprise. Regulations are part of doing business, and your compliance with them helps protect operators as well as consumers from potential liabilities.

You can best address the regulatory bureaucracy by taking it one step at a time. This publication helps you understand regulations, and ANR Publication 8334 explains where to start with these regulations in relation to your agritourism enterprise. You can also learn more about other aspects of the agritourism business in Agritourism and Nature Tourism in California (George and Rilla, 2005).

"Agritourism" means any income-generating activity conducted on a working farm or ranch for the enjoyment and education of visitors. This includes the interpretation of the natural, cultural, historical, and environmental assets of the land and the people working on it. Agritourism helps you build supportive relationships with the consuming public both in rural communities and in agricultural areas on the urban fringe. Increased public interaction with area farms and ranches builds an understanding and appreciation for working landscapes that can help maintain or enhance natural resource values too. 


\section{Understanding Regulations}

Regulations are constraints imposed by federal, state, and local governments, or the legal conditions placed upon your agritourism enterprise. These constraints go hand-in-hand with developing a business plan: you can't know which regulations affect your business until you've thought through your plan, and you can't finish your business plan until you know what you're allowed to do and the financial cost.

Introducing agritourism activities to your facility triggers additional legal requirements. If you are new to agricultural production and processing and you are also starting an agritourism enterprise, you have a lot to learn about regulations!

California law consists of 29 codes that cover a variety of subjects. As you contemplate a new enterprise you may be interested in the Fish and Game Code, the Health and Safety Code, the Food and Agriculture Code, the Business and Professions Code, or the Labor Code. Look for references within these codes at http://www.leginfo.ca.gov/calaw.html. Many county codes are also online at http://www.ordlink.com.

\section{Basic Regulation Categories}

To start an agritourism enterprise, you must comply with local requirements and you may need to obtain county zoning approval. You must adhere

Table 1

\section{County Agencies}

Planning Department

Building Department

Environmental Health Department

Public Works Department

Agricultural Commissioner: Weights and Measures Division

Fire Agency

Tax Collector
Oversees and makes recommendation on land use issues. Coordinates approval process for land use permits.

Enforces building codes for new or remodeled structures and issues building permits.

Enforces health codes for food facilities and evaluates new development plans for adequacy of public water supply, septic systems, and environmental impacts of waste disposal.

Analyzes traffic impacts of development projects and maintains county roads. Issues permits for county-road signs and grading.

Oversees the organic registration process, which can include a site inspection and the use of organic labels. Regulates commercial weighing and measuring devices to ensure accuracy. Issues farmers' market permits. Issues certified producer certificates that allow farmers to actually sell at certified farmers' markets.

Establishes county fire-prevention codes and enforces them through safety and occupancy inspections.

Collects taxes for different taxing agencies within the county. Issues business licenses. to regulations that protect the environment, your neighbors, and your visitors. The following sections and tables describe the categories and agencies relevant to agritourism.

\section{Understanding Land Use and Land Development Regulations}

\section{County Zoning \\ Jurisdiction: County \\ Contact: Planning Department}

Zoning permission is the first step in establishing your agritourism enterprise. You need to contact your county planning department about zoning laws that pertain to your property.

Each county has a "general plan" that describes its land use policies. Maps that show the county's land use zones are usually included in the general plan. County zoning governs how parcels in each land use one can be used. Typically, counties update their general plans every 10 years. This update requires a review and sometimes a revision of the zoning and development codes. It's a good idea to stay familiar with the zoning and development codes specific to your land.

\section{Agricultural zoning policies protect} farmlands and ranch lands from uses detrimental to agriculture. Zoning codes list allowed farming uses and compatible nonfarming uses for agriculturally zoned land. Each county decides what uses to allow and what conditions or standards to impose on these uses.

Zoning codes distinguish between nonfarm uses that are permitted by right and uses that require a Use Permit. Uses that require a Use permit are subject to conditions, review, and approval. "Permitted by right" means the proposed land use is allowed without special approval as long as it meets zoning and other requirements.

Each county defines its own permit types. Many counties have more than one type of use permit, each with its own type of requirements. The section "Putting the Pieces Together: The Use Permit Approval Process" in ANR Publication 8334 explains the steps you must follow to obtain a use permit. 


\author{
Table 2

\section{State Agencies} \\ Department of Public Health \\ CALTRANS (state transportation department) \\ California Environmental Quality Act (CEQA) (state law \\ describing environmental protection standards) \\ Department of Alcoholic Beverage Control \\ Department of Industrial Relations
}

Some counties have special ordinances for certain agritourism enterprises. These ordinances specify legal requirements and often offer a streamlined permitting process.

Typically, counties update their general plans every 10 years. This update requires a review and sometimes revision of the zoning and development codes. It's a good idea to stay familiar with the zoning and development codes specific to your land.

\section{Building Codes \\ Jurisdiction: County \\ Contact: Building Department}

When you make structural changes to your operation, you must conform to building code standards. When you renovate old buildings or

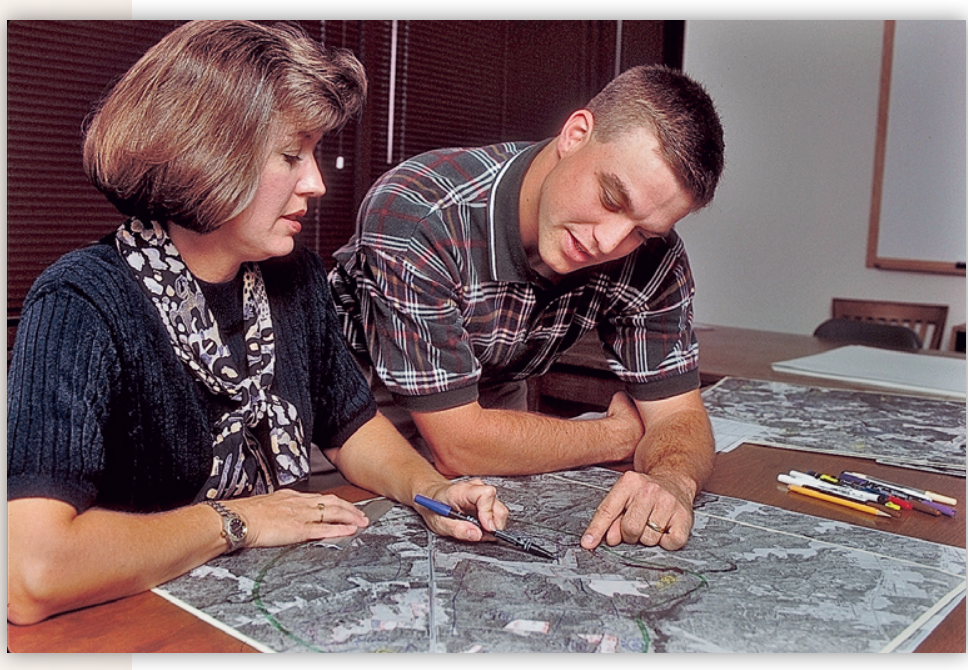

Table 3

\section{Federal Agencies}

U.S. Forest Service; Bureau of Land Management

Issues permits for commercial use of public lands.

Internal Revenue Service
Issues Employer Identification Number (EIN) to employer.
Enforces the California Health and Safety Code. Inspects food-processing facilities regarding products exported from the county.

Reviews development proposals for traffic-flow impacts. Issues permits for state-highway signs.

Enforced at county level.

Issues liquor licenses.

Sets occupational health and safety standards. (Employers must have a health and safety plan.)

construct new facilities, you must obtain a building permit from your county's building codes office. Note that all public-use structures must conform to accessibility standards of the Americans with Disabilities Act.

\section{Roads and Traffic}

Jurisdiction: State and County

Contact: CALTRANS, County Planning Department and Public Works Department

Your agritourism enterprise means visitors come to your farm or ranch, which means increased traffic on the roads. If your proposal requires a use permit, your county's planning and public works departments and/or CALTRANS will review it for public safety concerns related to roads and traffic. They might demand you widen or grade the road passing your property or build a turn-off or bridge.

\section{Use of Public Lands}

Jurisdiction: Federal or State

Contact: District Office of the U.S. Forest Service, Bureau of Land Management, or other appropriate agency

If you conduct commercial activities or business on federal- or state-owned lands, you must obtain a "special-use" permit from the land management agency on which the activities are proposed. Permits are required for certain recreational activities when they take place on public lands that host or charge fees. These could be an ongoing part of your operation such as horseback riding, guided fishing or hunting activities, or events including endurance rides, eco-races, chuckwagon dinners, etc.

The purpose of the permit process is to identify any potential land use or resource conflicts that might arise; to identify applicable procedures, permits, and special conditions needed to protect resources and public uses; to achieve common 
understanding between the agency and the applicant about the proposed uses; and to clarify timeframes, limitations, and responsibilities.

It is important that you make early contact (a year in advance isn't too early) with your local representative of the Forest Service, Bureau of Land Management, or other appropriate agency to discuss your proposal. District personnel will guide you through a process to determine if the proposal justifies submitting a special-use permit application. If you file an application for a special-use permit, you must provide a map and written description, supply detailed and specific information about your event or activity, and show proof of insurance with the agency listed as additionally insured.

Regulations are important to the development and cost estimates of a business plan; identify them early in your planning. The time required for the permit approval process varies with each operation; allow for a lengthy procedure.
Then, based on your permit application, project description, and potential environmental impacts, the district ranger makes the decision on whether to issue the special-use permit. The capacity of the proposed activity and interest from additional applicants may result in a competitive process for issuing permits. You must pay a processing fee and perhaps a monitoring fee before you receive your special-use permit. Some agencies also require that you pay them a percentage of the fees you collect. Special-use permits can be for one-time, one-day events (such as a bike and run eco-race) or for up to five years, such as horseback trail rides in conjunction with your ranch.

\section{Signs}

Jurisdiction: State or County

Contact: CALTRANS, County Planning Department and Public Works Department

Signs identifying and advertising your enterprise are subject to regulations. Signs on your own property are subject to county development and design codes. Signs on county roads are subject to county public works department rules. And signs on state highways face state transportation department restrictions.

\section{Understanding Public Health and Safety Regulations}

\section{Food Safety}

Jurisdiction: State Law

Contact: State and County Environmental Health
Departments

The California Uniform Retail Food Facilities Law (CURFFL) is part of the California Health and Safety
Code. It is the state law that governs food sanitation for food handling, processing, and preparation activities of the agritourism industry.

Specifically, CURFFL details food-safety requirements concerning food handling, equipment, and storage. These requirements are generally stricter for processed foods than they are for nonprocessed foods. According to CURFFL, processed foods sold to the public cannot be prepared in a home kitchen.

CURFFL is enforced at the local level by the county environmental health department. This department reviews plans and regularly inspect food facilities in accordance with state law. If you plan to construct a food facility (for example, to sell pies made from fruit grow on your farm) or modify an existing structure into such a facility, the county environmental health department first must approve your plan. Log onto your county's environmental health department Web site for CURFFL policies or view the California Department of Health Services Web site, http://www.dhs.ca.gov/, and search the site for CURFFL. The text of the law can be found in the California Health and Safety Code $\$ \$ 113700$ to 114475.

\section{Food Handler's Certificate \\ Jurisdiction: State and County}

Contact: County Environmental Health Department

CURFFL mandates that at least one person in an enterprise processing or preparing food for the public possess a current "food handler's certificate." This person may be either the business owner or an employee. You or your employees can earn a food handler's certificate by taking food safety courses from local service agencies. Contact your county environmental health department to learn when and where courses are offered.

\section{Agricultural Homestays \\ Jurisdiction: State and County}

Contact: County Environmental Health Department

Some agricultural operators establish on-farm bed and breakfasts (B\&Bs), also called farmstays or agricultural homestays. A 1998 law, AB 1258, amended California's Health and Safety Code to include an "agricultural homestay" establishment. This law allows working farms to host a limited number of overnight visitors and permits farm families to serve meals cooked in the farm kitchen to visitors, consistent with the federal Food Code definition of a family home kitchen. 
An agricultural homestay establishment must meet all of the following requirements:

- It contains no more than six guest rooms and hosts no more than fifteen guests.

- It provides overnight visitor accommodations.

- It serves food to registered guests only and serves meals at any time, with those prices included in the price of overnight accommodation.

- Lodging and meals are incidental and not the primary function of the agricultural homestay establishment.

- The agricultural homestay establishment is located on the farm and is part of a farm, as defined, and produces agricultural products as its primary source of income.

County agency web sites and staff can answer questions, provide information, and help you meet requirements. Tip: a good working relationship with all agency staff is vital, both during the permitapplication process and during later inspections.
Farmstay kitchens are regularly inspected by the county department of environmental health. Agricultural homestays must meet all other applicable state and local regulations and zoning requirements as well. Article 18 of CURFFL addresses the regulations for agricultural homestay establishments; see "Restricted Food Service Transient Occupancy Establishment."

\section{Public Safety}

Jurisdiction: County

Contact: County Fire Agency, Sheriff's

Department

Agricultural operations involving the public must comply with public safety and accessibility regulations such as those concerning emergency-exit access (fire safety) and restroom facilities. There are also local ordinances and codes for fire prevention and safety, including requirements relating to fire extinguishers and on-site water. Contact your local fire agency and sheriff's department to ensure that your activities conform to local ordinances.

\section{Understanding Environmental Health Regulations}

\section{Water}

Jurisdiction: County

\section{Contact: Environmental Health Department}

The county environmental health department reviews agritourism or nature tourism proposals to make sure there is adequate (in terms of quantity and quality) on-site water for visitors.

\section{Septic Systems}

Jurisdiction: County

\section{Contact: Environmental Health Department}

Each county has its own septic standards and usually requires a permit to repair, upgrade, or construct a septic system. If you're starting with a parcel of raw land, you'll need a site evaluation. That evaluation determines the suitability of on-site sewage disposal and the sewage treatment system that best fits your site and soil. If you already have an existing septic system, the environmental health department will evaluate your proposed site for its adequacy to accommodate farm visitors.

To avoid excessive cost and aggravation, it is important you work closely with your county. It is possible that alternate or additional systems are required even if they do not actually seem necessary.

\section{Understanding Direct-Marketing Regulations}

Jurisdiction: State and County

Contact: County Agricultural Commissioner

\section{Weights and Measures}

If you sell goods directly to the public by weight, then states require that you annually license your scales with the county weights and measures division. This requirement ensures your scales are properly calibrated and have passed inspection.

\section{Package Labeling}

If you package your fresh or processed products, you must attach a label that identifies the product, your business name, address, and net contents in terms of weight or other measure. It is the agricultural commissioner's weights and measures division that enforces this requirement.

\section{Organic Registration}

If you produce and sell organic products in California, the California Organic Foods Act of 2003 requires that you register your enterprise with your county agricultural commissioner. In addition, if you produce or sell an organic product and your gross sales are over $\$ 5,000$ annually, you must also be certified by a USDA-accredited organic certifier.

\section{Farmers' Market Permits}

If you operate a booth and sell produce/certifiable agricultural products at a certified farmers' market, you must obtain a Certified Producers Certificate 
(CPC) from the county agricultural commissioner where the market resides.

\section{Understanding Business Regulations}

\section{Fictitious Business Name Statement \\ Jurisdiction: State Law \\ Contact: County Recorder's Office}

If you select a business name that includes neither your surname nor another owner's name, you must file a "fictitious business name statement." You can find and file that form at the office of the county clerk or recorder. Your statement then will become a public document, kept on file with others until it expires or you abandon your endeavor. To avoid redundancy with other enterprises, search names already on file as you contemplate the name of your new enterprise. Within 30 days of filing the fictitious business name statement, you must publish it in a newspaper of general circulation within your county. You must do so once each week for 4 successive weeks.

\section{Business License \\ Jurisdiction: County \\ Contact: Tax Collector's Office}

Every person who does business in a California county must hold a California business license. In general, business licenses are issued after you've received clearance from other county departments. To obtain your business license, get an application form from the county tax collector's office. Complete it and submit the application form along with a nonrefundable fee to the county tax collector's office. Your form will go to all county departments for review and approval. Once it's approved, you'll receive a business license in the mail. You must post this license in a conspicuous place on your premises. And you must renew it annually, paying a fee each time you do so.

\section{Liquor License}

Jurisdiction: State

Contact: Department of Alcoholic Beverage Control $(A B C)$

There are many kinds of liquor licenses. In California, log onto the Web site of the Department of Alcoholic Beverage Control (http://www.abc. ca.gov) for extensive and detailed information and instructions.
Applying for your liquor license requires that you visit the nearest office of the Department of Alcoholic Beverage Control. (See the ABC Web site for office locations.) According to $\mathrm{ABC}$ instructions, you must apply in person because "considerable detailed personal information is required, including fingerprints from all individual applicants, managers, and managing officers of applicant corporations. Moreover, it is desirable for an employee of the department to advise all applicants in person of pertinent laws, rules, and regulations."

It will take $\mathrm{ABC}$ between 30 and 50 days to issue your license. You can apply for a new license or you can have a license transferred to you by a person or business with an existing license. Licenses must be renewed yearly, and require an annual renewal fee.

\section{Transient Occupancy Tax \\ Jurisdiction: State and County \\ Contact: County Tax Collector}

If you operate an agricultural homestay or farm B\&B, you must pay a "transient occupancy tax" (TOT). TOT is a state tax on revenues generated locally from the hotel, motel, and accommodations industry. In many counties and in some incorporated towns, the TOT includes a local tax as well as the state tax. County TOT rates range from 5 to 12 percent of the accommodation fee. Often, county boards of supervisors will use the county TOT funds to support promotional and advertising campaigns organized by the local chamber of commerce or convention and visitors' bureau.

You must collect the TOT from your visitors and remit the funds quarterly to the county tax collector. But first you must register your enterprise with the county tax collector and obtain a "transient occupancy registration certificate." Like your business license, this certificate needs to be displayed conspicuously on your farm or ranch.

\section{Labor Laws}

Labor laws are often the most difficult with which to comply. Because the number of regulations is increasing, it is important you know laws governing migrant labor, minimum wages, workplace safety, and special taxes.

The California Chamber of Commerce (www. calchamber.com) is a good resource for federal and state labor law information. The U.S. Department of Labor's Office of Small Business Programs helps small businesses comply with rules, regulations, and laws 
enforced by the U.S. Department of Labor

(www.dol.gov/dol/osbp) or toll-free at (888) 972-7332.

Additionally, the University of California

Agricultural Personnel Management Program

(http://apmp.berkeley.edu) offers information about

labor-related topics.

\section{Employer Identification Number \\ Jurisdiction: Federal \\ Contact: Internal Revenue Service}

If you hire employees specifically for any of your agritourism enterprises, you must obtain an employer identification number (EIN) and a federal tax identification number. When you send a completed SS-4 form to the IRS, you will register your business with the IRS, the Social Security Administration, and the Department of Labor. And you'll receive a federal tax identification number in the mail.

\section{Occupational Health and Safety}

Jurisdiction: State

Contact: Department of Industrial Relations

Businesses that hire employees must prepare an injury and illness plan. To help you create a safe and healthy workplace, the state offers a no-fee consultation. In California, you might have to obtain certain permits, licenses, and certificates to comply with the state's Health and Safety Standards.

\section{Employee State-Tax Registration}

Jurisdiction: State

Contact: Employment Development Department

Employers must register with the state for employee state-tax issues.

\section{Resources}

\section{CalGOLD: California Government: On-Line to Desktops Business Permits Made Simple}

This website provides California businesses owners with information on permits, licenses, and other requirements of all levels of government agencies. http://www.calgold.ca.gov_

\section{The California Planners' Book of Lists}

This web site contains contact information for California city and county planning agencies and is updated annually.

http://www.calpin.ca.gov/archives/default.asp

\section{References}

George, Holly, and Ellie Rilla. 2008. Agritourism enterprises on your farm or ranch: Where to start. Oakland: University of California, Division of Agriculture and Natural Resources, Publication 8334.

Keith, D., E. Rilla, H. George, R. Lobo, L. Tourte, and R. Ingram. 2003. Obstacles in the agritourism regulatory process: Perspectives of operators and officials in ten California counties. Davis: University of California Agricultural Issues Center. 22:1-6.

Rilla, E., and H. George, eds. 2005. Agritourism and nature tourism in California. Oakland: University of California Division of Agriculture and Natural Resources, Publication 3484. 


\section{FOR FURTHER INFORMATION}

To order or obtain ANR publications and other products, visit the ANR Communication Services online catalog at http://anrcatalog.ucdavis.edu or phone 1-800-994-8849. You can also place orders by mail or FAX, or request a printed catalog of our products from

University of California

Agriculture and Natural Resources

Communication Services

6701 San Pablo Avenue, 2nd Floor

Oakland, California 94608-1239

Telephone 1-800-994-8849

(510) 642-2431

FAX (510) 643-5470

E-mail: danrcs@ucdavis.edu

\section{Publication 8333}

ISBN-13: 978-1-60107-580-2

(02008 The Regents of the University of California Division of Agriculture and Natural Resources All rights reserved.

No part of this publication may be reproduced, stored in a retrieval system, or transmitted, in any form or by any means, electronic, mechanical, photocopying, recording, or otherwise, without the written permission of the publisher and the authors.

The University of California prohibits discrimination or harassment of any person on the basis of race, color, national origin, religion, sex, gender identity, pregnancy (including childbirth, and medical conditions related to pregnancy or childbirth), physical or mental disability, medical condition (cancer-related or genetic characteristics), ancestry, marital status, age, sexual orientation, citizenship, or status as a covered veteran (covered veterans are special disabled veterans, recently separated veterans, Vietnam era veterans, or any other veterans who served on active duty during a war or in a campaign or expedition for which a campaign badge has been authorized) in any of its programs or activities. University policy is intended to be consistent with the provisions of applicable State and Federal laws.

Inquiries regarding the University's nondiscrimination policies may be directed to the Affirmative Action/Staff Personnel Services Director, University of California, Agriculture and Natural Resources, 1111 Franklin Street, $6^{\text {th }}$ Floor, Oakland, CA 94607-5201, (510) 987-0096. For information about ordering this publication, telephone 1-800-994-8849.

To simplify information, trade names of products have been used. No endorsement of named or illustrated products is intended, nor is criticism implied of similar products that are not mentioned or illustrated.

$u c$

REVIEWED This publication has been anonymously peer reviewed for technical accuracy by University of California scientists and other qualified professionals. This review process was managed by the ANR Associate Editor for Farm Management and Economics.

pr-11/08-AS/CR 